Article

\title{
Performance Assessment Based on the Relative Efficiency of Indian Opencast Coal Mines Using Data Envelopment Analysis and Malmquist Productivity Index
}

\author{
Biswaranjita Mahapatra *, Chandan Bhar and Sandeep Mondal \\ Department of Management Studies, Indian Institute of Technology (Indian School of Mines), \\ Dhanbad 826004, India; chandanbhar@hotmail.com (C.B.); sandeepmondal@iitism.ac.in (S.M.) \\ * Correspondence: biswa.cet@gmail.com; Tel.: +91-9078341727
}

Received: 26 June 2020; Accepted: 13 September 2020; Published: 18 September 2020

check for updates

\begin{abstract}
Coal is the primary source of energy in India. Despite being the second-largest coal-producing country, there exists a significant difference in demand and production in India. In this study, the relative efficiency of twenty-eight selected opencast mines from a large public sector undertaking coal company in India for 2018-2019 was assessed and ranked by using data envelopment analysis (DEA). This study used input-oriented DEA with efficiency decomposition to pure technical efficiency, technical efficiency, and scale efficiency. The result showed that $25 \%$ and $36 \%$ of mines were efficient in technical efficiency and pure technical efficiency, respectively, whereas the eight mines scale efficiency was inefficient with a decreasing return to scale. Further, in this study, the Malmquist Productivity Index (MPI) was employed to measure the efficiency of the selected mines for three consecutive years (2016-2017 to 2018-2019). The result shows that in only three mines the efficiency is continuously improving from 2016-2017 to 2018-2019, whereas in more than $20 \%$ of mines the efficiency score is decreasing. Comparing the MPI efficiency and productivity assessment throughout the years, changes in innovation and technology are increasing from 2017-2018 to 2018-2019. Finally, the study concluded with a comprehensive evaluation of each variable with mines performance. The author formulated the strategies, which in turn help coal professionals to improve the efficiency of the mine.
\end{abstract}

Keywords: coal mines efficiency; data envelopment analysis; Indian opencast mines; Malmquist productive index

\section{Introduction}

Coal is the primary source of energy in India. Coal mining significantly contributes to the economy of India as it is used as a prime source for electrical energy needs. Coal is used in electricity generation, steel and cement production, and other industrial activities like paper, textiles, etc. During 2018-2019, electricity generating units consumed 637.95 Million tonnes of coal, followed by the steel and washery industries (69.50 Million Tonnes), the cement industry (8.82 Million tonnes), and the paper industry (1.64 Million tonnes) [1]. Every year the Planning Commission of India has been estimating the demand of coal in advance to meet the requirement [2]. Coal India Limited produces more than four-fifths of the coal produced in the country. Hence, India is more or less dependent on the company to produce the coal needed in the country. Despite being the second-largest coal-producing country, there exists a significant difference in demand and production. Therefore, the performance of the Indian coal company must be measured and assessed, so that strategies are formulated to improve the performance.

Performance measurement is used to supervise and control organizational activities to achieve predefined objectives [3]. Traditional business performance measures have been financial such as cost, 
profit margin, rate of return, cash flow, etc. Performance measures may typically fall into effectiveness, efficiency, quality, timeliness, productivity, or safety categories. Performance measurement creates the basis for an organization to access how well it is progressing towards its predetermined objectives, helps to identify the areas of strengths and weaknesses, which may result in taking future initiatives in improving organizational performance [4]. From the discussion mentioned above on performance measurement, coal mines need a better performance measurement system for measuring their performance. The issues around the performance of coal mines have become a subject of increasing complexity and confusion. Numerous authors have tried to study the performance of coal mines, and significant research reports are available in the field of efficiency and productivity of the mines.

Thompson et al. (1995) developed a new theory for assessing the performance of Illinois coal mining by using two different measures of data envelopment analysis (DEA) that is profit ratio and technical efficiency [5]. Then, Kulshreshtha and Parikh in 2002, attempted to carry out an extensive performance analysis of 30 different regions of Indian coal mining using the Malmquist index for a long run between 1985 to 1997 [6]. The study highlights the detailed analysis to improve productivity growth and technological change for both mines and suggestions given to improve the performance of both underground and opencast mines [6]. Hosseinzadeh et al. in 2016 examined loss or gain in the efficiency of the Australia mining sector over the period 2008-2014 by using bootstrap DEA [7]. The result shows that metal processing or mining services lead to the mines becoming more efficient than exploration and extraction activities [7]. Another study by Geissler et al. in 2015 measured, compared, and analyzed the technical efficiency of phosphate rock mining by using DEA [8].

Coal efficiency has gained a great deal of attention from Chinese academics [9]. Therefore, Fang et al., in 2009, presented a comparative efficiency analysis report on Chinese and United States coal mining companies using Charnes, Cooper, and Rhodes (CCR) and Banker, Charnes, and Cooper (BCC) models in the advanced DEA linear programming [9].

Some studies primarily focus on the coal resources, performance indicators, or selection of variables (inputs and outputs) for assessing performance. Lei and Riji in 2008 suggested an input-oriented efficiency assessment of coal mine safety. The result shows mines safety should lead to improved efficiency by effective utilization of funds and management resources [10]. Yijia et al. (2015) measure the utilization efficiency of China's coal resources using a three-stage data envelopment analysis and bootstrap DEA models [11].

The undesirable and uncontrollable variables are also considered in assessing the mine's performance. One of the studies incorporates both undesirable output and uncontrollable variables in performance assessment of Chinese coal-fired power plants by using data envelopment analysis by Yang and Pollitt in 2009 [12].

Most research papers focus on China, the United States, and Australian mines. It has also been observed from the literature review that the performance of coal mines in India is somewhat neglected by the research scientists. Defining the performance of coal mines and determining how to improve coal mines performance is still an unsolved issue in India. It has been observed that in India, barring a few studies, a thorough study on analyzing the performance-related issues of coal mines is conspicuously absent. As the Coal industry primarily focuses on efficiency rather than effectiveness, the performance of the organization depends on efficiency only by taking into account multiple aspects. From the literature review, it was concluded that DEA is a popular tool and is widely used for measuring coal performance in terms of efficiency and productivity. The DEA technique has the following advantages over other methods for evaluating performance; (1) the DEA considers multidimensional aspects of coal mines as it deals with multiple inputs and outputs of the different units; (2) this method does not require any prior information on weights. Instead, DEA automatically assigns weights after evaluation; (3) the functional relationship among the input and output variables is not considered for efficiency evaluation in DEA; (4) DEA provides a benchmark value which helps coal professionals to set a target for achieving the goal; (5) this method is much more flexible in that it 
easily integrates with other methods like the analytic hierarchy process (AHP), balanced scorecard (BSC), and other structural modeling techniques.

The present study is an attempt to develop a framework to manage the performance of Indian coal mines and to bridge the existing gap by using the DEA. Further, the coal mine's performance was monitored for a particular period. As time changes, there are also changes in policy, rules, and regulations, the adaption of new technology, changes in working methods or techniques which may affect the organizational performance. Sometimes a change in organizational structure also affects the performance in terms of loss or gain. The Malmquist productivity index, a method used for longitudinal evaluation over time, has also been discussed based on the literature review. The objective of the study is to analyze whether the performance of coal mines declines in a particular year or a consecutive period, by using the Malmquist index. The research analyzes the performance of coal mining from 2016-2017 to 2018-2019 using the Malmquist productivity index, which is broken down into efficiency changes and technical change.

\section{Materials and Methods}

\subsection{Data Envelopment Analysis}

Charnes and Cooper introduced the DEA in 1978 as a nonparametric linear programming-based methodology used for performance evaluation [13,14]. It evaluates the relative efficiency of each department or organization or unit or member, which is called decision making units (DMUs). The DEA technique divides the DMUs into two categories, i.e., efficient and inefficient, and provides the benchmark value for each inefficient DMU. It individually ranks all the efficient DMUs as rank one and inefficient DMUs as less than one [14].

There are two basic versions of the data envelopment analysis, the Charnes, Cooper, and Rhodes (CCR) version, which provides a constant returns to scale (CRS) measure, and the Banker, Charnes, and Cooper (BCC) version, which offers a variable returns to scale (VRS) measure [14,15]. The CRS principle is applied where there is a constant change for both input and output variables. If input reduces by ' $X$ times, then the output will increase by $X$ ' times. The mathematical expression of the CCR model is given below [14,15];

$$
\begin{gathered}
\text { Maximize } h_{0}=\max \sum_{r=1}^{s} U_{r} Y_{r 0} \\
\text { Subject to } \\
\sum_{i=1}^{m} v_{i} X_{i 0}=1 \\
\sum_{r=1}^{m} u_{r} Y_{r j}-\sum_{i=1}^{m} v_{i} X_{i j} \leq 0, j=1, \ldots, n \\
u_{r} \geq \varepsilon, r=1, \ldots, s \\
v_{i} \geq \varepsilon, i=1, \ldots, m
\end{gathered}
$$

where, $u_{r}$, the weight for output $r$; $v_{i}$ the weight for input $I ; y_{r j}$, the amount of output $r$ of $\mathrm{DMU}_{\mathrm{j}} ; x_{i j}$, the amount of input $I$ of $\mathrm{DMU}_{\mathrm{j}}$; $s$, the number of output; $m$, the number of input; $n$, the number of DMUs; and $\varepsilon$, a small positive number [14]

The VRS principle is applied where the input will not proportionally change with output. Similarly, the BCC model is expressed below [15];

$$
\text { Maximize } h_{0}=\max \sum_{r=1}^{s} u_{r} Y_{r 0}-u_{0}
$$




$$
\begin{gathered}
\text { Subject to } \\
\sum_{i=1}^{m} v_{i} X_{i 0}=1 \\
\sum_{r=1}^{m} u_{r} y_{r j}-u_{0}-\sum_{i=1}^{m} v_{i} x_{i j} \geq 0, j=1, \ldots, n \\
u_{r} \geq \varepsilon, r=1, \ldots, s \\
v_{i} \geq \varepsilon, i=1, \ldots, m
\end{gathered}
$$

$u_{0}$ unrestricted in sign

The symbols used in the BCC model have already been explained in the CCR model.

The efficiency obtained from CCR is called technical efficiency, meaning the development level of efficiency in current and future scale [16]. The efficiency obtained from BCC, termed pure technical efficiency, indicates the current efficiency level [16]. Scale efficiency is the ratio of technical efficiency to pure technical efficiency, which represents the trend of efficiency with the increase in development scale [16]. Both CCR and VRS models are used in this study. The management has eased control over the input variables rather than the output. Therefore, the study uses an input-oriented measure with radial distance.

\subsection{Malmquist Productivity Index}

The Malmquist Productivity Index (MPI) was first suggested by Malmquist in 1953 [17], then developed as a productivity index by Caves et al. in 1982 [18], and then further developed by Fare et al. in 1994 [19] as the Malmquist DEA performance measure [20].

An essential feature of the DEA Malmquist index is that it can break down the overall efficiency measure into two mutually exclusive components, one measuring the change in technical efficiency (catch-up effect) and the other measuring change in technology (innovation) [20]. To avoid choosing different benchmarks for productivity and efficiency, and so obtaining different results, Fare, Grosskopf, Norris, and Zhang [19] suggested using the geometric mean of the two in the final MPI [20];

$$
\mathrm{MPI}^{0}=\left[\frac{D_{0}^{t+1}\left(Z^{t+1}\right)}{D_{0}^{t}\left(Z^{t}\right)}\right] \times\left[\left(\frac{D_{0}^{t}\left(Z^{t+1}\right)}{D_{0}^{t+1}\left(Z^{t+1}\right)}\right)\left(\frac{D_{0}^{t}\left(Z^{t}\right)}{D_{0}^{t+1}\left(Z^{t}\right)}\right)\right]^{\frac{1}{2}}
$$

So, the Malmquist efficiency index is the product of efficiency change and technology change from the period $t$ to $t+1$. The technical change enables coal professionals to identify contributions of improved technical productivity and technological progress to productivity growth of the coal mining industry.

In this research, $t$ refers to the year 2016-2017 and $t+1$ consider 2017-2018 and 2018-2019. If the MPI score is higher than one, then there is an improvement in efficiency from $\mathrm{t}$ to $t+1$. An MPI index equal to one and less than one indicates no change and decrease in efficiency, respectively. This paper examines the trend in the performance of the coal industry from 2016-2017 to 2018-2019 using the MPI and discusses the reason behind it.

\subsection{Selection of Input and Output Variables for Performance Measurement}

The coal mining industry is a complex structure. Thus, identifying the performance measurement indicators has been an essential task for the researcher. Initially, the performance measurement indicators were created from secondary sources and a survey of the existing literature resulted in acquiring the indicators. The interaction with coal mines professionals helped the author to arrive at eight sets of performance indicators. For this study, the performance measurement indicators focus 
on three significant aspects of the coal mining company: financial, operational, and customer. These indicators are further divided into input and output variables for measuring the performance of coal mines using the DEA. The details of the performance measurement indicator are shown in Figure 1

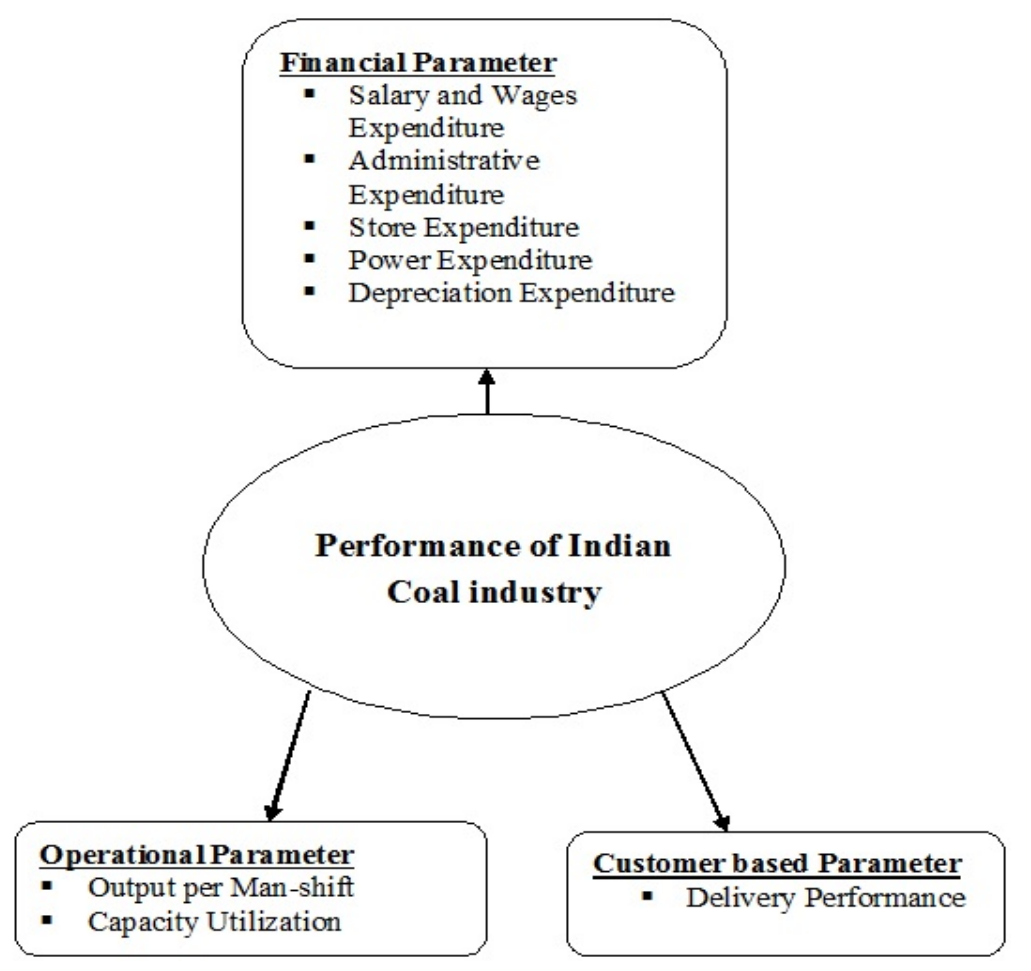

Figure 1. The Performance measurement indicator.

Further, five input variables were selected from the financial aspect, namely salary and wages expenditure, administrative expenditure, store expenditure, power expenditure, and depreciation expenditure. The justification behind choosing input indicators is that salary and wages cost the coal industry between $50-60 \%$ of the total cost, which is directly related to its cost-effectiveness. This is because the coal industry mainly focuses on the employee because the optimum utilization of employee not only reduces the cost but also improves the production. The higher output with less man-shift increases efficiency. The other selected costs, which account for a $40 \%$ share of the total cost, focus on: administration expenditure; oil, explosive; store parts; depreciation of the machinery and the power utilization by the mines, and are the major cost drivers in the coal mining company. These costs have a direct impact on coal efficiency. The three output variables are chosen from two operational aspects, namely output per man-shift, capacity utilization, and one customer-aspect, namely, delivery performance. The mines must ensure achievement of the goal by proper use of resources like man, machine, equipment, etc. Manpower plays a vital role in coal mines productivity, and therefore OMS should be optimized to improve the productivity of a mine. Again, lower capacity utilization of mines reduces the efficiency of the mine. So, the capacity of the mine must be utilized to improve the performance. Customer satisfaction primarily depends on the quality and quantity of the coal delivered as per the target date. The amount of coal despatch by the mine is planned prior, and it varies from mine to mine. There should not be a gap between the target and actual coal despatch. Therefore, the study focus on the percentage target coal despatch achieved by the mines instead of using the direct quantity of Despatch. As the Indian coal mine industry mainly focuses on efficiency-based performance and less on effectiveness, operational parameters become essential for indicating the performance of the organization.

The detailed description of the input and output variables are presented below: 
1. Salary and wages expenditure (rupees/tonne): Salary and wages paid to the employee (salary of executive and staff; gratuity; regular and overtime duty; Sunday/holiday over time payment; fall back wages; leave travel concession; long leave travel concession and other perks)

2. Administrative expenditure (rupees/tonne): Security/central industrial security force, head office expenditure, area office expenditure, etc.

3. Store expenditure (rupees/tonne): Store expenditure contains different store items used for mines operation like POL (petroleum oil lubricant), explosive, spare parts of the machine, etc.

4. Power expenditure (rupees/tonne): Power consumed by the individual mine per unit. The power is consumed through several sources like electricity, coal, and diesel, etc., based on the mine's requirement.

5. Depreciation expenditure (rupees/tonne): Depreciation costs involved in the capital items. Depreciation involves wear and tear occur to the mining asset per annum.

6. Output per man-shift (tonne): Output in terms of coal production per total number of miners working in shift per annum.

7. Capacity utilization (percentage): Percentage of the capacity of mines utilized. Here, capacity utilization considers the overall capacity utilization of the mines, considering man and machine utilization.

8. Delivery performance (percentage): Percentage of the coal delivered by the mine.

The delivery performance expressed as the ratio of actual coal despatch to the target coal despatch. Where:

Actual coal despatch $=$ Actual amount of coal despatch by a mine per annum.

Target coal despatch $=$ Amount of coal despatch Target set by the mine based on demand per annum

The name of the input and output variables along with their notion and reference is presented in Table 1.

Table 1. The input-output variables, their notation, and references.

\begin{tabular}{ccccccccc}
\hline S.L. No. & Input Variables & Notation & References & S.L. No. & Output Variables & Notation & References \\
\hline 1 & $\begin{array}{c}\text { Salary and Wages } \\
\text { Expenditure }\end{array}$ & SWE & {$[7]$} & 1 & Output per Man-shift & OMS & Expert opinion \\
\hline 2 & $\begin{array}{c}\text { Administrative } \\
\text { Expenditure }\end{array}$ & AE & {$[7]$} & 2 & Capacity Utilization & CU & [21,22] \\
\hline 3 & Store Expenditure & SE & $\begin{array}{c}\text { Expert } \\
\text { opinion }\end{array}$ & 3 & Delivery Performance & DP & - & - \\
\hline 4 & Power Expenditure & PE & $\begin{array}{c}\text { Expert } \\
\text { opinion }\end{array}$ & - & & - & - \\
\hline 5 & $\begin{array}{c}\text { Deppert } \\
\text { Expecinion }\end{array}$ & DE & - & & - & - \\
\hline
\end{tabular}

\subsection{Data Collection}

The coal mine's performance is achieved by fulfilling the target of each mine. The statistical data used in this paper are adopted from a large public sector undertaking coal company. The data used in this study were collected from the company's cost sheet, production report and performance report, etc. Some mines are ignored due to a large variability within the data and to maintain homogeneity among the mines. In this study, twenty-eight (28) open cast mines are considered as a set of DMUs for measuring performance. Due to data security, mines names are given as OC1, OC2-OC28 instead of using their original mines name. The data of consecutive three years from 2016-2017 to 2018-2019 are used in this study based on the model requirement. The input and output data regarding the opencast mines are presented in Appendix A. As discussed, the data mentioned above used in this paper are only to explain and validate the said model. 


\section{Results}

This study aims to achieve the following objectives: (1) measure the different relative efficiencies of the selected opencast mines by using the DEA; (2) benchmark the mines with actual and projected values; (3) the study uses the Malmquist DEA model to analyze the efficiency change and productivity change for three consecutive years; (4) discuss the reasons why there are differences in performance and formulate the strategies for further improvement.

\subsection{DEA Result for Opencast Mines}

The data were incorporated into the DEA model to demonstrate the application and run by using the MaxDEA Pro software [14].

\subsubsection{Efficiency Result from CCR and BCC Models}

The result obtained allows the classification of opencast mines into a set of efficient mines with a relative efficiency score of one and a set of inefficient mines with a relative efficiency of less than one. It is observed from Table 2 that based on the input-oriented variable return to scale principle, nearly $36 \%$ mines, namely (OC1, OC3, OC4, OC 8 , OC9, OC10, OC12, OC14, OC19, and OC23) are efficient and the rest of the 18 mines are inefficient. The result changes drastically when the constant return to scale is applied. This result presents seven mines, namely OC1, OC3, OC8, OC9, OC10, OC19, and $\mathrm{OC} 23$ as being efficient, and the rest as being inefficient. Considering the three different types of efficiency score, OC5, OC17, OC 27, and OC28 show a low-efficiency score of less than $40 \%$. These four mines need more attention to analyze the reason behind the inefficiency, and strategies should be made for further improvement.

Table 2. The input-oriented data envelopment analysis (DEA) efficiency result for opencast mines. DMU: decision making units.

\begin{tabular}{|c|c|c|c|c|c|c|}
\hline \multirow[b]{2}{*}{ No. } & \multirow[b]{2}{*}{ DMUs } & \multirow[b]{2}{*}{$\begin{array}{c}\text { Benchmark (Lambda) Based } \\
\text { on an Input-Oriented } \\
\text { Variable Return to Scale }\end{array}$} & \multicolumn{3}{|c|}{ Efficiency } & \multirow[b]{2}{*}{$\begin{array}{l}\text { Return to } \\
\text { Scale }\end{array}$} \\
\hline & & & $\begin{array}{c}\text { Pure } \\
\text { Technical } \\
\text { Efficiency }\end{array}$ & $\begin{array}{l}\text { Technical } \\
\text { Efficiency }\end{array}$ & $\begin{array}{c}\text { Scale } \\
\text { Efficiency }\end{array}$ & \\
\hline 1 & OC1 & OC01(1.000000) & 1.00 & 1.00 & 1.00 & Constant \\
\hline 2 & OC2 & $\begin{array}{l}\text { OC01 }(0.543096) ; \\
\text { OC03(0.189614); } \\
\text { OC10 }(0.267290)\end{array}$ & 0.90 & 0.85 & 0.95 & Decreasing \\
\hline 3 & OC3 & OC03(1.000000) & 1.00 & 1.00 & 1.00 & Constant \\
\hline 4 & OC4 & OC04(1.000000) & 1.00 & 0.71 & 0.71 & Decreasing \\
\hline 5 & OC5 & $\begin{array}{l}\text { OC01 }(0.213842) ; \\
\text { OC03(0.122542); } \\
\text { OC23(0.663616) }\end{array}$ & 0.52 & 0.31 & 0.60 & Increasing \\
\hline 6 & OC6 & $\begin{array}{l}\text { OC01(0.346575); } \\
\text { OC09(0.130785); } \\
\text { OC12(0.421276); } \\
\text { OC23(0.101365) }\end{array}$ & 0.47 & 0.43 & 0.92 & Decreasing \\
\hline 7 & OC7 & $\begin{array}{l}\text { OC01(0.792683); } \\
\text { OC23(0.207317) }\end{array}$ & 0.98 & 0.73 & 0.75 & Increasing \\
\hline 8 & OC8 & OC08(1.000000) & 1.00 & 1.00 & 1.00 & Constant \\
\hline 9 & OC9 & OC09(1.000000) & 1.00 & 1.00 & 1.00 & Constant \\
\hline 10 & OC10 & $\begin{array}{l}\text { OC10(1.000000) } \\
\text { OC01(0.075745); }\end{array}$ & 1.00 & 1.00 & 1.00 & Constant \\
\hline 11 & OC11 & $\begin{array}{l}\text { OC03(0.480075); } \\
\text { OC19(0.444180) }\end{array}$ & 0.61 & 0.45 & 0.73 & Increasing \\
\hline
\end{tabular}


Table 2. Cont.

\begin{tabular}{|c|c|c|c|c|c|c|}
\hline \multirow[b]{2}{*}{ No. } & \multirow[b]{2}{*}{ DMUs } & \multirow[b]{2}{*}{$\begin{array}{l}\text { Benchmark (Lambda) Based } \\
\text { on an Input-Oriented } \\
\text { Variable Return to Scale }\end{array}$} & \multicolumn{3}{|c|}{ Efficiency } & \multirow[b]{2}{*}{$\begin{array}{c}\text { Return to } \\
\text { Scale }\end{array}$} \\
\hline & & & $\begin{array}{c}\text { Pure } \\
\text { Technical } \\
\text { Efficiency }\end{array}$ & $\begin{array}{l}\text { Technical } \\
\text { Efficiency }\end{array}$ & $\begin{array}{c}\text { Scale } \\
\text { Efficiency }\end{array}$ & \\
\hline 12 & OC12 & OC12(1.000000) & 1.00 & 0.95 & 0.95 & Decreasing \\
\hline 13 & OC13 & $\begin{array}{l}\text { OC01(0.205182); } \\
\text { OC03(0.399035); } \\
\text { OC19(0.006487); } \\
\text { OC23(0.389297) }\end{array}$ & 0.77 & 0.61 & 0.78 & Increasing \\
\hline 14 & OC14 & OC14(1.000000) & 1.00 & 0.92 & 0.92 & Decreasing \\
\hline 15 & OC15 & $\begin{array}{l}\text { OC01(0.188982); } \\
\text { OC08(0.198657); } \\
\text { OC23(0.612361) }\end{array}$ & 0.55 & 0.53 & 0.96 & Increasing \\
\hline 16 & OC16 & $\begin{array}{l}\text { OC01(0.319492); } \\
\text { OC08(0.235384); } \\
\text { OC09(0.004227); } \\
\text { OC19(0.141816); } \\
\text { OC23(0.299080) }\end{array}$ & 0.71 & 0.69 & 0.97 & Increasing \\
\hline 17 & OC17 & $\begin{array}{l}\text { OC01(0.071571); } \\
\text { OC08(0.126618); } \\
\text { OC10(0.207025); } \\
\text { OC19(0.205100); } \\
\text { OC23(0.389686) }\end{array}$ & 0.35 & 0.34 & 0.96 & Increasing \\
\hline 18 & OC18 & $\begin{array}{l}\text { OC01(0.798755); } \\
\text { OC09(0.067988); } \\
\text { OC19(0.081270); } \\
\text { OC23(0.051988) }\end{array}$ & 0.88 & 0.82 & 0.94 & Decreasing \\
\hline 19 & OC19 & OC19(1.000000) & 1.00 & 1.00 & 1.00 & Constant \\
\hline 20 & OC20 & $\begin{array}{l}\text { OC01(0.105459); } \\
\text { OC08(0.760717); } \\
\text { OC23(0.133824) }\end{array}$ & 0.68 & 0.61 & 0.90 & Increasing \\
\hline 21 & OC21 & $\begin{array}{l}\text { OC19(0.188535); } \\
\text { OC23(0.811465) }\end{array}$ & 0.94 & 0.92 & 0.98 & Increasing \\
\hline 22 & OC22 & $\begin{array}{l}\text { OC08(0.518162); } \\
\text { OC23(0.481838) }\end{array}$ & 0.62 & 0.55 & 0.89 & Increasing \\
\hline 23 & OC23 & OC23(1.000000) & 1.00 & 1.00 & 1.00 & Constant \\
\hline 24 & OC24 & $\begin{array}{l}\text { OC01(0.306705); } \\
\text { OC10(0.075647); } \\
\text { OC19(0.150502); } \\
\text { OC23(0.467145) }\end{array}$ & 0.55 & 0.53 & 0.96 & Decreasing \\
\hline 25 & OC25 & $\begin{array}{l}\text { OC01(0.416175); } \\
\text { OC10(0.102251); } \\
\text { OC19(0.182750); } \\
\text { OC23(0.298824) }\end{array}$ & 0.42 & 0.41 & 1.00 & Decreasing \\
\hline 26 & OC26 & $\begin{array}{l}\text { OC01(0.274775); } \\
\text { OC08(0.070309); } \\
\text { OC10(0.098436); } \\
\text { OC19(0.186510); } \\
\text { OC23(0.369970) }\end{array}$ & 0.55 & 0.54 & 0.98 & Increasing \\
\hline 27 & OC27 & $\begin{array}{l}\text { OC01(0.071272); } \\
\text { OC08(0.114583); } \\
\text { OC19(0.406252); } \\
\text { OC23(0.407894) }\end{array}$ & 0.37 & 0.35 & 0.94 & Increasing \\
\hline 28 & OC28 & $\begin{array}{l}\text { OC01(0.215875); } \\
\text { OC08(0.028252); } \\
\text { OC19(0.250679); } \\
\text { OC23(0.505193) }\end{array}$ & 0.31 & 0.24 & 0.76 & Increasing \\
\hline
\end{tabular}


The benchmarking (lambda) presents the peer benchmarking group for each inefficient mine and its peer value lambda. The DEA automatically assigns the efficient mines as benchmarking mines or group of efficient mines as a peer group for each inefficient mine. For example, in the case of $\mathrm{OC} 2$, the peer benchmark mines are OC1, OC3, and OC10. The lambda values are OC1 (0.543096); OC3(0.189614); OC10(0.267290). The coal mine's manager can use the benchmark value for the inefficient mines.

\subsubsection{Target Values and Sources of Inefficiency}

The DEA result not only categories the DMUs but also provides the projected value for the input and output variables of each inefficient mine. The value for input and output variables of opencast mines is obtained from the DEA result. The projected values are the benchmark values that convert the inefficient mines into efficient ones. For example, OC28 has already been declared as an inefficient mine with a score of 0.312 . However, it can become efficient if it uses the above-mentioned projected value instead of the actual value for both input and output variables. The input variable decreased with SWE (salary and wages expenditure) used 467.84 instead of 1501, AE (administrative expenditure) 166.13, SE (store expenditure) 131.22, PE (power expenditure) 43.83, and DE (depreciation expenditure) 72.93 , and similarly output variable improved with OMS (output per man-shift) 6.81 , capacity utilization to $80.76 \%$, and delivery performance to $84.28 \%$.

As the cost of salary and wages shares about $50-60 \%$ of the total cost, it must be reduced to maximize the profit. The percentage change in variable with actual and projected value is presented in Appendix B. Out of 18 inefficient mines, ten mines needed more than a $50 \%$ reduction in salary and wages cost. The maximum reduction in input variables projected to $80.24 \%$ SWE for OC18, $68.83 \%$ AE for OC28, 68.83\% SE for OC28, and 88.23\% PE for OC18, and $82.67 \%$ DE for OC15.

The highest average percentage increase in output variable is required for OMS. The benchmark values for output variables noticed that except for seven inefficient mines, the other eleven mines need to improve their OMS by more than $100 \%$. The OC2, OC7, and OC5 mines required significant improvements in capacity utilization by $350.55 \%, 331.62 \%$, and $228.22 \%$, respectively. As compared to OMS and CU, there are less requirements for improvements in delivery performance noticed. Except for OC21 with $76.22 \%$ and OC5 with $66.14 \%$, the other ten mines projected less than a $42 \%$ improvement in delivery performance. Interestingly, sixteen mines need no change in delivery performance.

\subsection{Evaluating Coal Mines Performance Using Malmquist Productive Index}

The selected opencast mines are taken into consideration to analyses the trend in productivity and efficiency change by using input-oriented variable return to scale of Malmquist index from a period of three years (2016-2017 to 2018-2019).

The significant result is marked in Table 3 that from 2016-2017 to 2017-2018, for twelve mines the Malmquist Index becomes one and more than one. There was an efficiency improvement or technological improvement or a combination of both. As compared to the previous year, the Malmquist index for 2017-2018 to 2018-2019 shows an increasing trend for eight mines (OC1, OC3, OC5, OC7, OC8, OC9, OC14, OC24) due to less change in efficiency (mines that change in efficiency score less than one). The result shows that only three mine's efficiency continuously improved from 2016-2017 to 2018-2019, whereas in more than $20 \%$ of mines the efficiency score is decreasing. Comparing the MPI efficiency and productivity assessment among the years, change in innovation and technology is increasing from 2017-2018 to 2018-2019. Comparing years, changes in innovation and technology increased from 2017-2018 to 2018-2019, but productivity growth declines in terms of efficiency. Therefore, the study aims to analyze the efficiency from 2016-2017 to 2018-2019 and discuss the reasons behind it. 
Table 3. The Malmquist Productivity Index (MPI) result of opencast mines.

\begin{tabular}{|c|c|c|c|c|c|c|c|c|c|c|}
\hline NO. & DMU & $\begin{array}{c}\text { Efficiency } \\
(2016-2017)\end{array}$ & $\begin{array}{c}\text { Efficiency } \\
\text { (2017-2018) }\end{array}$ & $\begin{array}{c}\text { Efficiency } \\
\text { (2018-2019) }\end{array}$ & $\begin{array}{l}\text { Efficiency Change } \\
\text { (2016-2017 to } \\
\text { 2017-2018) }\end{array}$ & $\begin{array}{l}\text { Efficiency Change } \\
\text { (2017-2018 to } \\
2018-2019)\end{array}$ & $\begin{array}{c}\text { Technological } \\
\text { Change (2016-2017 } \\
\text { to 2017-2018) }\end{array}$ & $\begin{array}{c}\text { Technological } \\
\text { Change (2017 to } \\
\text { 2018) }\end{array}$ & $\begin{array}{c}\text { Malmquist } \\
\text { Index } \\
\text { (2016-2017 to } \\
\text { 2017-2018) }\end{array}$ & $\begin{array}{c}\text { Malmquist } \\
\text { Index (2017-2018 to } \\
\text { 2018-2019) }\end{array}$ \\
\hline 1 & OC1 & 1.000 & 1.000 & 3.340 & 1.000 & 3.340 & 1.000 & 1.000 & 1.000 & 3.340 \\
\hline 2 & OC2 & 1.059 & 0.582 & 0.464 & 0.550 & 0.797 & 1.041 & 1.070 & 0.572 & 0.853 \\
\hline 3 & OC3 & 0.786 & 0.580 & 1.000 & 0.739 & 1.723 & 1.047 & 1.013 & 0.774 & 1.746 \\
\hline 4 & OC4 & 2.753 & 1.005 & 0.949 & 0.365 & 0.944 & 2.201 & 1.000 & 0.803 & 0.944 \\
\hline 5 & OC5 & 0.514 & 0.274 & 0.309 & 0.533 & 1.126 & 1.000 & 1.000 & 0.533 & 1.126 \\
\hline 6 & OC6 & 1.000 & 1.720 & 0.217 & 1.720 & 0.126 & 0.706 & 1.644 & 1.214 & 0.207 \\
\hline 7 & OC7 & 0.460 & 0.369 & 0.569 & 0.801 & 1.543 & 1.000 & 1.000 & 0.801 & 1.543 \\
\hline 8 & OC8 & 0.880 & 0.545 & 1.000 & 0.619 & 1.836 & 1.000 & 1.000 & 0.619 & 1.836 \\
\hline 9 & OC9 & 0.380 & 0.382 & 0.510 & 1.006 & 1.337 & 0.983 & 1.017 & 0.989 & 1.360 \\
\hline 10 & OC10 & 0.920 & 0.856 & 0.714 & 0.931 & 0.834 & 1.000 & 1.000 & 0.931 & 0.834 \\
\hline 11 & OC11 & 0.349 & 1.415 & 0.530 & 4.056 & 0.374 & 0.575 & 1.894 & 2.334 & 0.708 \\
\hline 12 & OC12 & 0.722 & 1.000 & 0.475 & 1.384 & 0.475 & 2.835 & 0.379 & 3.924 & 0.180 \\
\hline 13 & OC13 & 0.706 & 0.552 & 0.421 & 0.781 & 0.763 & 1.144 & 1.021 & 0.894 & 0.779 \\
\hline 14 & OC14 & 0.601 & 0.567 & 1.000 & 0.944 & 1.763 & 1.107 & 1.000 & 1.045 & 1.763 \\
\hline 15 & OC15 & 0.620 & 0.403 & 0.370 & 0.650 & 0.918 & 1.148 & 1.000 & 0.746 & 0.918 \\
\hline 16 & OC16 & 0.476 & 1.000 & 0.429 & 2.103 & 0.429 & 1.000 & 1.000 & 2.103 & 0.429 \\
\hline 17 & OC17 & 0.729 & 0.303 & 0.251 & 0.415 & 0.830 & 1.232 & 1.040 & 0.512 & 0.863 \\
\hline 18 & OC18 & 0.429 & 0.500 & 0.428 & 1.167 & 0.855 & 1.100 & 1.000 & 1.283 & 0.855 \\
\hline 19 & OC19 & 0.922 & 0.761 & 6.214 & 0.826 & 8.161 & 1.000 & 1.000 & 0.826 & 8.161 \\
\hline 20 & OC20 & 1.000 & 1.000 & 0.534 & 1.000 & 0.534 & 0.799 & 1.000 & 0.799 & 0.534 \\
\hline 21 & OC21 & 0.725 & 0.485 & 0.729 & 0.669 & 1.504 & 1.000 & 1.000 & 0.669 & 1.504 \\
\hline 22 & OC22 & 0.500 & 0.595 & 0.523 & 1.190 & 0.879 & 1.000 & 1.000 & 1.190 & 0.879 \\
\hline 23 & $\mathrm{OC} 23$ & 1.000 & 1.132 & 1.000 & 1.132 & 0.884 & 0.658 & 1.006 & 0.744 & 0.889 \\
\hline 24 & OC24 & 0.357 & 0.408 & 0.350 & 1.141 & 0.859 & 0.985 & 1.080 & 1.124 & 0.927 \\
\hline 25 & OC25 & 0.278 & 0.299 & 0.259 & 1.076 & 0.866 & 1.008 & 1.039 & 1.085 & 0.900 \\
\hline 26 & OC26 & 0.358 & 0.400 & 0.366 & 1.116 & 0.914 & 0.966 & 1.035 & 1.078 & 0.947 \\
\hline 27 & OC27 & 0.354 & 0.372 & 0.298 & 1.052 & 0.800 & 0.991 & 1.185 & 1.043 & 0.948 \\
\hline 28 & OC28 & 0.283 & 0.255 & 0.231 & 0.899 & 0.906 & 1.006 & 1.061 & 0.904 & 0.961 \\
\hline
\end{tabular}




\section{Discussion}

From the above DEA result, it is concluded that twenty-one open cast mines are inefficient due to high salary and wages expenditure, store expenditure, and low OMS and capacity utilization. At the same time, OC19 and OC23 are mechanized mines resulting in high productivity and low cost. The optimum utilization of men and machine lead to improvements in productivity and capacity utilization of mines. Therefore, the machine breakdown must be reduced through scheduled preventive maintenance. Additionally, the machine availability hour increased to improve utilization. Further mines, namely, OC8, OC9, and OC10, outsource some major activities like overburden removal and local transport for coal despatch in and around the coalfield to improve efficiency.

The study also highlights a longitudinal analysis of mine performance for three years by using the MPI. The five different efficiency trends have been highlighted from the MPI result and represented in the Figure 2.

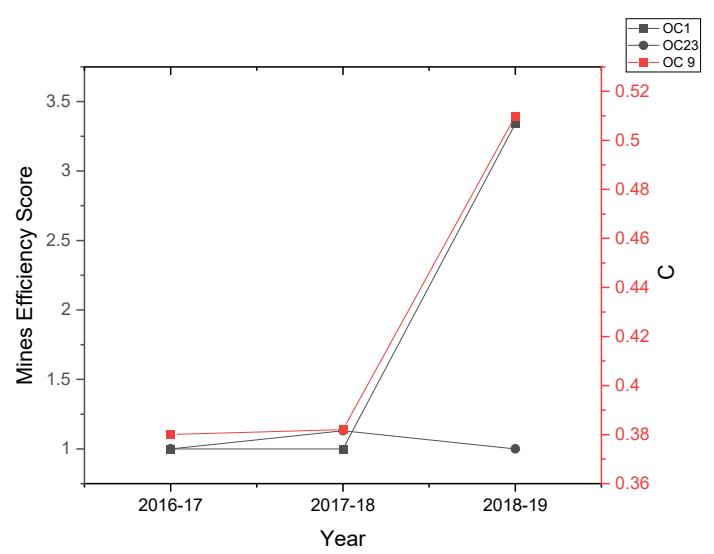

(a) Efficient for three years

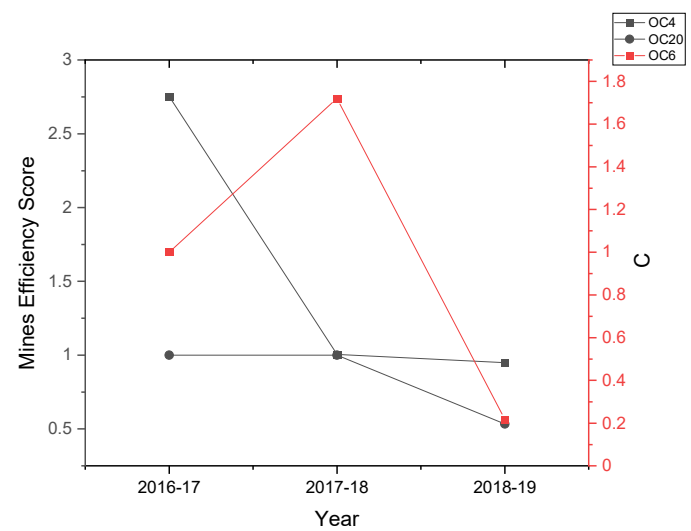

(b) First two years efficient, then decrease to inefficient 


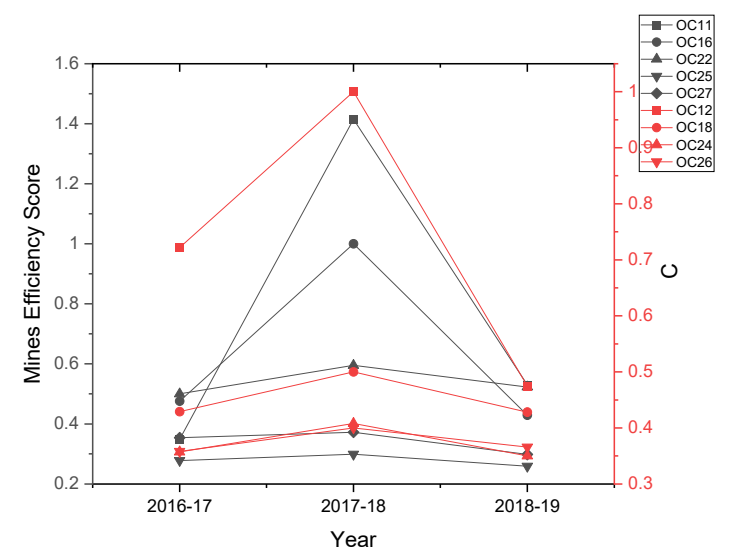

(c) First increase efficiency score then decrease

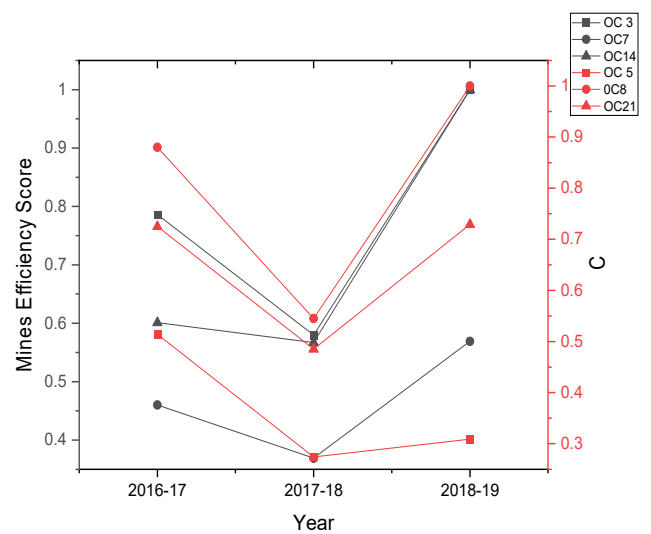

(d) First decrease efficiency score then increase

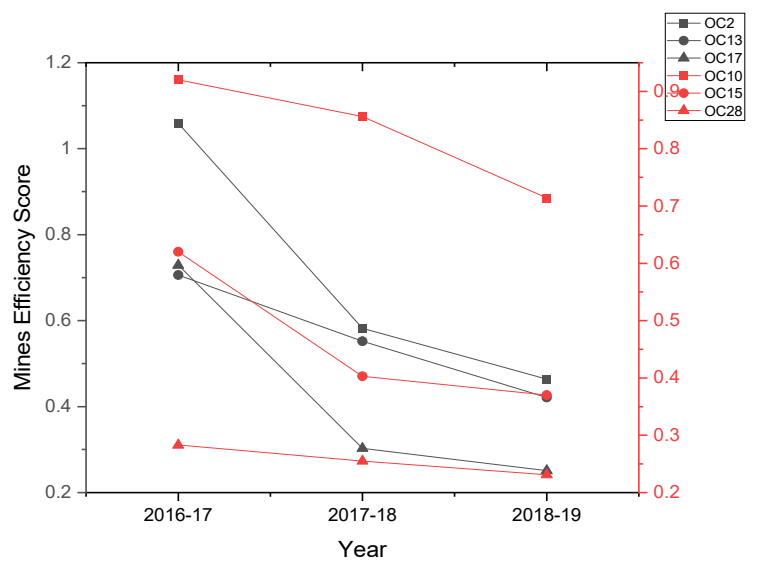

(e) Continuously decreasing efficiency score

Figure 2. The Efficiency Trend analysis of opencast mines from 2016-2017 to 2018-2019.

The three mines (OC1, OC9, and OC23) steadily increasing from 2016-2017 to 2018-2019. This trend was due to an increase in SWE and SE to 8-10\% from 2016-2017 to 2017-2018, then a decrease in 2018-2019. The other cost decreases from 2016-2017 to 2018-2019, whereas in OC1, both the PE and AE increase. The OMS is continuously increasing. The CU and DP first decrease then increase. 
The OC4, OC6, and OC20 mines remain efficient for the first two years then decrease their scores. The mines OC6 and OC20 always remain efficient for the first two years then decrease their scores to nearly $60 \%$ and $40 \%$, respectively. All costs slightly increase by $10 \%$ to $20 \%$ from 2016 to 2017 , but more than a $50 \%$ increase in all costs is noticed in 2018-2019. The OMS is decreasing. The CU and DP decrease in 2017-2018, but more than a 40\% decrease in CU occurs in 2018-2019.

The reverse effect is shown in the case of mines OC3, OC5, OC7, OC8, OC14, and OC21. The mines are inefficient in the year 2016-2017, then they suddenly increased their performance to become efficient for the next years. Then mines score decrease in 2018-19 as compared to the previous year. The SWE is increasing for all three mines and the $\mathrm{DE}$ is decreasing. Other costs (PE, AE, SE) increases from 2016-2017 to 2017-2018 then decrease. For OC3, OC5, OC7, OC21 OMS, CU, and DP first decrease then increase. In other mines the OMS is increasing and the CU and DP increase then decrease.

Some peculiar results were noticed for nine mines (OC11, OC12, OC16, OC18, OC22, OC24, OC25, OC26, OC27), whose efficiency score first decreased from 2016-17 to 2017-18 then suddenly increased in 2018-19 as compared to the previous year. This effect is due to only SE decreasing, but all the other costs SWE, AE, PE, DE decrease then increase. The CU and DP increase then decrease. For OC25, OC26, OC27 the OMS decreases, then increases, and for other mines, the OMS increases then decreases.

The mines OC2, OC10, OC13, OC15, OC17, and OC28 need to receive special attention as their efficiency score gradually decreases from 2016-2017 to 2018-2019. The reason behind the decrease in efficiency is due to the high cost and less OMS and CU. The DP does not show a significant change from 2016-2017 to 2018-2019. Lastly, whatever the efficiency trend may be-increasing, decreasing, or combination of both-some mines show less than a 50\% efficiency score for all above mentioned years. Additionally, to improve the relative efficiency of opencast mines, close monitoring of input utilization is required, and the corrective action must be taken to improve their performance.

There is always scope for improvement regarding resources. This study aims to focus on the input and output variables affecting the relative efficiency of a mine. The author formulates a set of possible strategies practiced in the coal industry. The primary objective of the strategy formulation originated from the efficiency result of the coal mines. Based on the relative efficiency result discussed, the aim should be to minimize the individual input variables and improve output variables. The strategies are formulated to control the input variables and improve the output variables based on the structure, workflow, and operational principles of the coal industry.

\subsection{Strategies for the Reduction of Input Variables}

\subsubsection{Salary and Wages Cost and Performance}

The salary and wages cost contribute $50-60 \%$ of the total cost. The reduction in salary and wages costs, in turn, gives less deployment of men, which again directly improves the OMS. As discussed in the result section, that most mine's efficiency scores (OC2, OC10, OC13, OC15, OC17, OC28) declined because of high salary and wages cost for both opencast and underground mines. The target values given to the inefficient mines like the OC2 can be converted into efficient ones if they use SWE 629.37 instead of 1588 . The proper utilization of man and machine should be required to control salary and wages cost. The overtime payment to the employees also leads to increases in the SWE, and the proper deployment of man and machine can minimize it. Increased automation with due regard to the environment, reliability (reliability of the equipment), and safety (both man and machine) may be introduced for both opencast and underground mines. There should be some control over the mining process, which leads to minimizing the unnecessary involvement of workers. The proper planning for easy extraction of coal and overburden is required inline to achieve the targeted production-vis-improvement productivity. Finally, considering technology up-gradation, the adoption of appropriate technology is the most economical way to reduce the SWE cost. 


\subsubsection{Administrative Cost and Performance}

From the efficiency result, it has been concluded that for some mines $(\mathrm{OC} 2, \mathrm{OC} 4, \mathrm{OC} 6, \mathrm{OC} 10$, OC13, OC15, OC17, OC24, OC28) the administrative cost increases from 2016-2017 to 2018-2019 due to lack of coordination among the administrative staff and greater use of manual office work which in turn increases office expenditure. The administrative cost can easily be controlled by adopting advanced technology. Increased automation to install a paperless office helps to greatly reduce the administrative cost. The installation of a modern surveillance system to improve security with minimal human resources deployment reduces administrative costs.

\subsubsection{Store Cost and Performance}

The store cost depends upon the amount of utilization of oil, lubricant, explosive and spare parts. The store cost is very high for the mines (OC2, OC6, OC7, OC10, OC13, OC14, OC15, OC17, OC28). The proper inventory control and management of material will lead to reducing the store cost. The optimum level of inventory shall be decided for each item considering the cost associated with inventory. Adequate monitoring must be done on the utilization of items issued from the store. There should be a reduction in obsolescence of material, which can be achieved through proper analysis of store items. Finally, the maintenance and housekeeping of stores should be ensured, which helps to minimize store cost.

\subsubsection{Depreciation Cost and Performance}

The result shows fewer mine's (OC8, OC10, OC 14, OC15, OC17, and OC28) depreciation cost increasing from 2016-2017 to 2018-2019. The depreciation cost of mines is mainly based on the life of the equipment. The increase in the life of the equipment is achieved by proper maintenance. There should be a restriction on the deployment of equipment under unfavorable working conditions. Finally, the selection of appropriate technology to reduce capital investment in the mine is necessary.

\subsubsection{Power Cost and Performance}

Though power cost shares $5-8 \%$ of the total cost, for some mines (OC2, OC10, OC 14, OC15), power cost increases from 2016-2017 to 2018-2019. The reduction in power cost is achieved through the efficient utilization of power and minimization of non-productive use of power. The power cost nowadays can be controlled through the installation of modern control systems to ensure minimum losses of power during operation.

\subsection{Strategies for the Improvement of Output Variables}

\subsubsection{OMS and Performance}

Mathematically, OMS is the ratio of production output to the number of miners working in a shift in a mine. Therefore, for a given production, if the manpower is decreased, the OMS will increase. The relative efficiency result highlights that improved OMS and reduced SWE results in the mines becoming efficient ones (OC1, OC9, OC23). The increased productivity also leads to an increase in the OMS, which is achieved through improved mechanization of operation and maintenance of the mine. Both mines should concentrate on proper mine planning for the easy extraction of coal and overburden inline to achieve the targeted production vis-à-vis improvement productivity with due regard to safety. The appropriate evacuation system in line with handling the bulk production of coal must be adopted. The mines must ensure to maintain time management to minimize the loss of resources. The reduction of man-shift is achieved by reducing the number of supporting and office employees. Ensuring adequate motivation of employees towards work and need-based deployment of manpower in mining operations may result in an improved OMS. 


\subsubsection{Capacity Utilization and Performance}

From the efficiency analysis, it is noted that mines' efficiency score depends upon the capacity utilization to a greater extent. The mines capacity utilization mainly depends upon how much mines capacity is being utilized. If, for example, one mines capacity is $200 \mathrm{MT}$ and its production is $150 \mathrm{MT}$, that means only $75 \%$ of the capacity of the mine has been utilized. The maximum capacity utilization of mines also results in increased productivity, which in turn improves the mine's efficiency. But the result also highlights that in some mines (OC2, OC10, OC13, OC15, OC17, OC28) the capacity utilization is decreasing from 2016-2017 to 2018-2019. Therefore, the capacity utilization of all subsystems and system as a whole should be achieved. Various operations should be allocated with optimum resources, and improved maintenance of equipment for better reliability during operation may increase the capacity of the mine. They must ensure adequate motivation of employees towards work.

\subsubsection{Delivery Performance and Mine Performance}

The delivery performance of the mines is based on customer-focused parameters, which depend on the coal dispatch achieved. Some mines (OC2, OC10, OC13, OC15, OC17, OC20, OC21, OC28) delivery performance decreasing from 2016 to 2018, which results in reducing the efficiency score. There are also mines whose delivery performance is low, as compared to benchmark mines. So, the delivery performance should be improved through the availability of adequate quality and quantity of coal for despatch. For coal dispatch, there should be the timely placement of rake for despatch of coal from the mine and ensuring adequate availability of bulk handling equipment and manpower for bulk transportation coal. The loading time must be minimized through developing the proper layout of coal loading systems.

The DEA and MPI results help the coal professionals to set a target for achieving organizational performance.

\section{Conclusions}

This study attempted to carry out a comprehensive efficiency assessment of selected twenty-eight opencast mines from a large public sector undertaking coal company in India by using the DEA. The result shows that only $25 \%$ mines (OC1, OC3, OC8, OC9, OC10, OC19, and OC23) are pure technical efficient and 36\% mines (OC1, OC3, OC4, OC 8 , OC9, OC10, OC12, OC14, OC19, and OC23) are technical efficient. The study also highlighted eight mines as being inefficient, showing a decreasing return to scale while considering scale efficiency. Considering three different types of efficiency decomposition, four mines (OC5, OC17, OC27, and OC28) have less than a 40\% relative efficiency score, which needs more attention towards improvement. These mine's efficiency decreases due to high a SWE and SE and a decreased value of OMS and capacity utilization. The study helps the coal professionals to efficiently utilize resources by providing the benchmark value for each inefficient mine.

The paper not only analyzes the relative efficiency among the mines but also assesses the performance of mines for a consecutive three years by using the DEA MPI method. Therefore, the study aims to analyze the trend in efficiency change from 2016-2017 to 2018-2019 and discuss the reason behind it. As compared to the previous year, the Malmquist index for 2017-2018 to 2018-2019 shows increasing change efficiency for eight mines (OC1, OC3, OC5, OC7, OC8, OC9, OC14, OC24) due to less change in the efficiency. Comparing the MPI efficiency and productivity assessment throughout the years, the change in innovation and technology is increasing from 2017-2018 to 2018-2019. The change in productivity in open cast mines is mainly driven by technological up-gradation. The coal company may pursue policy to encourage technology up-gradation through a global tender.

Based on the result, the performance indicators are better analyzed, and some implications are proposed at the mine site level. It is concluded that by referring some strategies to improve the performance of each variable, in turn this will help the coal professional to increase the coal mines efficiency. 
Finally, this study has a few constraints. Due to the restriction of the DEA model, the number of input and output variables is limited. Apart from these variables, other variables like flexibility, quality of coal, customer responsiveness, delivery time, etc. can also be used for future research on coal mine efficiency assessment. Some uncontrollable and undesirable variables, like inventory, can be used by different DEA techniques. The next study should expand the variables by integrating DEA with another tool like a Balanced Score Card.

Author Contributions: Conceptualization, B.M., C.B. and S.M.; methodology, B.M.; software, B.M.; validation, B.M., C.B. and S.M.; formal analysis, B.M.; investigation, B.M.; resources, B.M.; data curation, B.M.; writing-original draft preparation, B.M.; writing-review and editing, B.M., C.B. and S.M.; visualization, B.M.; supervision, B.M., C.B. and S.M., All authors have read and agreed to the published version of the manuscript.

Funding: This research received no external funding.

Acknowledgments: We: the authors, are very thankful to the Editor and reviewers for their support for our manuscript. The authors highly appreciate the useful comments and suggestions given by the Editor and reviewers on the initial version of this manuscript.

Conflicts of Interest: The authors declare no conflict of interest.

\section{Appendix A}

Table A1. Opencast Mines Data for 2018-2019.

\begin{tabular}{ccccccccc}
\hline MINES & SWE & AE & SE & PE & DE & OMS & CU & DP \\
\hline OC1 & 371 & 267 & 231 & 15 & 39 & 6.1 & 106.59 & 98.54 \\
OC2 & 1588 & 267 & 476 & 44 & 40 & 1.36 & 20.87 & 92 \\
OC3 & 1291 & 294 & 212 & 33 & 0 & 3.95 & 102.67 & 88.45 \\
OC4 & 1175 & 267 & 504 & 51 & 204 & 2.07 & 108.18 & 98.69 \\
OC5 & 1391 & 406 & 327 & 50 & 160 & 2.87 & 26.75 & 54.07 \\
OC6 & 1789 & 478 & 602 & 123 & 200 & 1.63 & 102.03 & 94.41 \\
OC7 & 1535 & 289 & 216 & 18 & 94 & 5.08 & 23.37 & 68.12 \\
OC8 & 462 & 113 & 234 & 22 & 59 & 9.14 & 50.92 & 52.03 \\
OC9 & 1489 & 203 & 421 & 74 & 73 & 2.34 & 104.51 & 89.24 \\
OC10 & 685 & 145 & 205 & 27 & 55 & 5.01 & 62.37 & 81.23 \\
OC11 & 1884 & 373 & 218 & 202 & 23 & 1.08 & 47.17 & 58.9 \\
OC12 & 1184 & 218 & 238 & 45 & 103 & 2.27 & 103.05 & 94.28 \\
OC13 & 865 & 292 & 242 & 36 & 67 & 3.21 & 57.19 & 72.54 \\
OC14 & 960 & 266 & 260 & 20 & 115 & 3.11 & 95.45 & 99.12 \\
OC15 & 835 & 280 & 473 & 44 & 506 & 3.53 & 45.95 & 82.54 \\
OC16 & 1986 & 246 & 247 & 47 & 90 & 3.09 & 79.39 & 72.18 \\
OC17 & 1518 & 420 & 420 & 119 & 202 & 1.64 & 57.8 & 78.39 \\
OC18 & 2526 & 280 & 252 & 228 & 50 & 1.22 & 101.67 & 94.29 \\
OC19 & 1134 & 150 & 14 & 103 & 25 & 2.53 & 65.44 & 69.15 \\
OC20 & 609 & 194 & 410 & 48 & 94 & 1.97 & 60.27 & 52.57 \\
OC21 & 705 & 217 & 125 & 45 & 142 & 7.7 & 45.45 & 47.69 \\
OC22 & 908 & 198 & 390 & 72 & 212 & 3.21 & 64.45 & 62.11 \\
OC23 & 179 & 134 & 141 & 28 & 112 & 9.11 & 79 & 87.5 \\
OC24 & 1045 & 323 & 280 & 98 & 131 & 4.23 & 78.71 & 87.65 \\
OC25 & 1215 & 465 & 389 & 121 & 144 & 4.78 & 82.3 & 88.1 \\
OC26 & 867 & 313 & 280 & 123 & 120 & 5.1 & 72.5 & 84 \\
OC27 & 1641 & 395 & 285 & 167 & 175 & 3.56 & 68.9 & 73.5 \\
OC28 & 1501 & 533 & 421 & 210 & 234 & 2.97 & 61.75 & 60.25 \\
\hline
\end{tabular}


Table A2. Opencast Mines Data for 2017-2018.

\begin{tabular}{ccccccccc}
\hline MINES & SWE & AE & SE & PE & DE & OMS & CU & DP \\
\hline OC1 & 246 & 194 & 87 & 9 & 33 & 8.44 & 185.38 & 94.86 \\
OC2 & 1126 & 229 & 306 & 28 & 34 & 2.1 & 115.89 & 92.57 \\
OC3 & 490 & 242 & 173 & 25 & 114 & 4.86 & 31.46 & 50.07 \\
OC4 & 438 & 229 & 158 & 20 & 10 & 4.52 & 32.03 & 54.34 \\
OC5 & 824.84 & 496 & 406 & 112 & 187 & 1.81 & 23.83 & 33.5 \\
OC6 & 542 & 318 & 195 & 20 & 83 & 4.17 & 90.86 & 98.34 \\
OC7 & 1220 & 281 & 602 & 143 & 199 & 1.24 & 28.8 & 47.21 \\
OC8 & 578 & 201 & 211 & 23 & 148 & 4.61 & 47.96 & 77.49 \\
OC9 & 1164 & 312 & 391 & 47 & 248 & 8.04 & 26.13 & 51.73 \\
OC10 & 432 & 121 & 167 & 32 & 64 & 4.49 & 86.76 & 88.38 \\
OC11 & 1040 & 311 & 225 & 56 & 14 & 2.46 & 76.12 & 91.31 \\
OC12 & 1191 & 290 & 232 & 49 & 79 & 2.1 & 126.89 & 98.45 \\
OC13 & 797.78 & 281 & 189 & 28 & 43 & 3.51 & 46 & 47.28 \\
OC14 & 719 & 267 & 198 & 19 & 102 & 3.71 & 49.61 & 71.43 \\
OC15 & 650 & 282 & 269 & 37 & 591 & 4.13 & 71.03 & 87.47 \\
OC16 & 860 & 234 & 581 & 147 & 427 & 0.67 & 189.75 & 97.21 \\
OC17 & 1111 & 394 & 349 & 82 & 156 & 2.12 & 37.21 & 49.05 \\
OC18 & 1586 & 207 & 240 & 193 & 203 & 1.73 & 66.32 & 72.5 \\
OC19 & 696 & 136 & 225 & 49 & 90.86 & 4.38 & 75.98 & 79.03 \\
OC20 & 392 & 271 & 164 & 34 & 144.73 & 7.65 & 119.17 & 98.34 \\
OC21 & 403 & 291 & 247 & 64 & 145.88 & 3.06 & 44.86 & 69.34 \\
OC22 & 893 & 174 & 374 & 67 & 198 & 3.15 & 62.5 & 63.5 \\
OC23 & 163 & 128 & 121 & 35 & 105 & 8.87 & 80.5 & 85.5 \\
OC24 & 987 & 310 & 255 & 103 & 127 & 4.21 & 72.23 & 74.5 \\
OC25 & 1111 & 423 & 347 & 123 & 136 & 4.89 & 87.11 & 85 \\
OC26 & 823 & 296 & 265 & 112 & 103 & 5.2 & 75.5 & 88.45 \\
OC27 & 1550 & 388 & 267 & 158 & 163 & 3.45 & 65.45 & 71.25 \\
OC28 & 1447 & 517 & 403 & 217 & 205 & 3.05 & 64 & 70.5 \\
\hline
\end{tabular}

Table A3. Opencast Mines Data for 2016-2017.

\begin{tabular}{|c|c|c|c|c|c|c|c|c|}
\hline MINES & SWE & $\mathrm{AE}$ & SE & PE & DE & OMS & CU & DP \\
\hline OC1 & 272.62 & 103.56 & 109.67 & 12.77 & 20.84 & 6.25 & 189.99 & 94.5 \\
\hline OC2 & 615.57 & 127.4 & 173.85 & 18.57 & 68.89 & 2.9 & 105.17 & 95 \\
\hline OC3 & 328.58 & 188.11 & 146.81 & 17.27 & 83.87 & 5.22 & 56 & 61.25 \\
\hline OC4 & 437.14 & 212.95 & 151.31 & 21.78 & 7.57 & 4.36 & 55.45 & 53.2 \\
\hline OC5 & 790 & 201.4 & 289.59 & 61.13 & 232.41 & 2.49 & 35.89 & 45 \\
\hline OC6 & 499.15 & 219.76 & 169.03 & 24.64 & 67.57 & 3.81 & 124.01 & 96.35 \\
\hline OC7 & 1111.24 & 225.21 & 295.17 & 86.59 & 142.2 & 2.06 & 61.5 & 76 \\
\hline OC8 & 582 & 117.64 & 187.85 & 29.87 & 74.22 & 3.51 & 50.53 & 51.11 \\
\hline OC9 & 974.28 & 272.87 & 425.49 & 89.93 & 202.93 & 2.5 & 140.28 & 87 \\
\hline OC10 & 425.28 & 112.6 & 120.51 & 26.96 & 51.92 & 4.65 & 92.22 & 93 \\
\hline OC11 & 1085.57 & 343.88 & 314.31 & 243.29 & 156.39 & 1.84 & 38.1 & 47.75 \\
\hline OC12 & 547.94 & 159.5 & 151.83 & 118.74 & 99.17 & 3.73 & 68.47 & 76.33 \\
\hline OC13 & 694 & 213.94 & 155.25 & 36.14 & 71.37 & 3.03 & 94.88 & 91.35 \\
\hline OC14 & 701.06 & 231.59 & 182.53 & 32.03 & 65.88 & 3.44 & 53.03 & 70 \\
\hline OC15 & 610.05 & 275.31 & 176.79 & 25.82 & 219.97 & 3.51 & 37.54 & 41.45 \\
\hline OC16 & 715.25 & 217.74 & 251.15 & 46.6 & 193.67 & 3.38 & 66.25 & 79.95 \\
\hline OC17 & 980.67 & 338.91 & 150.4 & 104.14 & 111.59 & 0.08 & 173.29 & 94.35 \\
\hline OC18 & 761.13 & 335.76 & 255.78 & 67.69 & 113.65 & 2.38 & 95.82 & 91.05 \\
\hline
\end{tabular}


Table A3. Cont.

\begin{tabular}{|c|c|c|c|c|c|c|c|c|}
\hline MINES & SWE & $\mathrm{AE}$ & SE & PE & DE & OMS & CU & DP \\
\hline OC19 & 571.49 & 112.36 & 199.66 & 43.22 & 37.41 & 3.14 & 68.34 & 78 \\
\hline OC20 & 275.91 & 136.32 & 144.47 & 45.59 & 89.81 & 8.1 & 159.89 & 94 \\
\hline OC21 & 402.79 & 142.92 & 209.68 & 46.9 & 87.49 & 5.69 & 102.83 & 93.25 \\
\hline OC22 & 887 & 207 & 521 & 67 & 207 & 3.07 & 61.38 & 73.08 \\
\hline OC23 & 158 & 128 & 155 & 17 & 78 & 9.07 & 54.23 & 81.93 \\
\hline OC24 & 907 & 345 & 307 & 87 & 94 & 4.52 & 76.5 & 82.25 \\
\hline OC25 & 1102 & 431 & 394 & 103 & 85 & 4.67 & 72.41 & 72.05 \\
\hline OC26 & 756 & 290 & 321 & 130 & 112 & 4.85 & 68.15 & 74.2 \\
\hline OC27 & 1411 & 370 & 310 & 124 & 141 & 3.21 & 61.25 & 63.5 \\
\hline OC28 & 1225 & 415 & 387 & 146 & 189 & 3.07 & 63.3 & 67 \\
\hline
\end{tabular}




\section{Appendix B}

Table A4. Comparisons between actual and projected value with percentage change of input variables of opencast mines using VRS DEA.

\begin{tabular}{|c|c|c|c|c|c|c|c|c|c|c|c|c|c|c|c|c|}
\hline SLNO & DMUs & $\begin{array}{l}\text { Actual } \\
\text { SWE }\end{array}$ & $\begin{array}{l}\text { Projected } \\
\text { (SWE) }\end{array}$ & $\begin{array}{c}\% \\
\text { Change }\end{array}$ & $\begin{array}{c}\text { Actual } \\
\text { AE }\end{array}$ & $\begin{array}{l}\text { Projected } \\
\text { (AE) }\end{array}$ & $\begin{array}{c}\% \\
\text { Change }\end{array}$ & $\begin{array}{c}\text { Actual } \\
\text { SE }\end{array}$ & $\begin{array}{l}\text { Projected } \\
\text { (SE) }\end{array}$ & $\begin{array}{c}\% \\
\text { Change }\end{array}$ & $\begin{array}{c}\text { Actual } \\
\text { PE }\end{array}$ & $\begin{array}{l}\text { Projected } \\
\text { (PE) }\end{array}$ & $\begin{array}{c}\% \\
\text { CHANGE }\end{array}$ & $\begin{array}{l}\text { Actual } \\
\text { DE }\end{array}$ & $\begin{array}{l}\text { Projected } \\
\text { (DE) }\end{array}$ & $\%$ CHANGE \\
\hline 1 & OC1 & 371 & 371.00 & $0 \%$ & 267 & 267.00 & $0.00 \%$ & 231 & 231.00 & $0 \%$ & 15 & 15.00 & $0 \%$ & 39 & 39.00 & $0 \%$ \\
\hline 2 & OC2 & 1588 & 629.37 & $60.37 \%$ & 267 & 239.51 & $10.30 \%$ & 476 & 220.45 & $53.69 \%$ & 44 & 21.62 & $50.86 \%$ & 40 & 35.88 & $10.30 \%$ \\
\hline 3 & OC3 & 1291 & 1291.00 & $0 \%$ & 294 & 294.00 & $0 \%$ & 212 & 212.00 & $0 \%$ & 33 & 33.00 & $0 \%$ & 0 & 0.00 & $0 \%$ \\
\hline 4 & OC4 & 1175 & 1175.00 & $0 \%$ & 267 & 267.00 & $0 \%$ & 504 & 504.00 & $0 \%$ & 51 & 51.00 & $0 \%$ & 204 & 204.00 & $0 \%$ \\
\hline 5 & OC5 & 1391 & 356.32 & $74.38 \%$ & 406 & 182.05 & $55.16 \%$ & 327 & 168.95 & $48.33 \%$ & 50 & 25.83 & $48.34 \%$ & 160 & 82.66 & $48.34 \%$ \\
\hline 6 & OC6 & 1789 & 840.25 & $53.03 \%$ & 478 & 224.51 & $53.03 \%$ & 602 & 249.68 & $58.52 \%$ & 123 & 36.67 & $70.19 \%$ & 200 & 77.81 & $61.10 \%$ \\
\hline 7 & OC7 & 1535 & 331.20 & $78.42 \%$ & 289 & 239.43 & $17.15 \%$ & 216 & 212.34 & $1.69 \%$ & 18 & 17.70 & $1.67 \%$ & 94 & 54.13 & $42.41 \%$ \\
\hline 8 & OC8 & 462 & 462.00 & $0 \%$ & 113 & 113.00 & $0 \%$ & 234 & 234.00 & $0 \%$ & 22 & 22.00 & $0 \%$ & 59 & 59.00 & $0 \%$ \\
\hline 9 & OC9 & 1489 & 1489.00 & $0 \%$ & 203 & 203.00 & $0 \%$ & 421 & 421.00 & $0 \%$ & 74 & 74.00 & $0 \%$ & 73 & 73.00 & $0 \%$ \\
\hline 10 & OC10 & 685 & 685.00 & $0 \%$ & 145 & 145.00 & $0 \%$ & 205 & 205.00 & $0 \%$ & 27 & 27.00 & $0 \%$ & 55 & 55.00 & $0 \%$ \\
\hline 11 & OC11 & 1884 & 1151.58 & $38.88 \%$ & 373 & 227.99 & $38.88 \%$ & 218 & 125.49 & $42.44 \%$ & 202 & 62.73 & $68.95 \%$ & 23 & 14.06 & $38.87 \%$ \\
\hline 12 & OC12 & 1184 & 1184.00 & $0 \%$ & 218 & 218.00 & $0 \%$ & 238 & 238.00 & $0 \%$ & 45 & 45.00 & $0 \%$ & 103 & 103.00 & $0 \%$ \\
\hline 13 & OC13 & 865 & 668.32 & $22.74 \%$ & 292 & 225.24 & $22.86 \%$ & 242 & 186.97 & $22.74 \%$ & 36 & 27.81 & $22.75 \%$ & 67 & 51.77 & $22.73 \%$ \\
\hline 14 & OC14 & 960 & 960.00 & $0.00 \%$ & 266 & 266.00 & $0.00 \%$ & 260 & 260.00 & $0.00 \%$ & 20 & 20.00 & $0.00 \%$ & 115 & 115.00 & $0.00 \%$ \\
\hline 15 & OC15 & 835 & 271.50 & $67.49 \%$ & 280 & 154.96 & $44.66 \%$ & 473 & 176.48 & $62.69 \%$ & 44 & 24.35 & $44.66 \%$ & 506 & 87.68 & $82.67 \%$ \\
\hline 16 & OC16 & 1986 & 447.93 & $77.45 \%$ & 246 & 174.11 & $29.22 \%$ & 247 & 174.82 & $29.22 \%$ & 47 & 33.26 & $29.23 \%$ & 90 & 63.70 & $29.22 \%$ \\
\hline 17 & OC17 & 1518 & 529.20 & $65.14 \%$ & 420 & 146.42 & $65.14 \%$ & 420 & 146.42 & $65.14 \%$ & 119 & 41.49 & $65.13 \%$ & 202 & 70.42 & $65.14 \%$ \\
\hline 18 & OC18 & 2526 & 499.04 & $80.24 \%$ & 280 & 246.23 & $12.06 \%$ & 252 & 221.60 & $12.06 \%$ & 228 & 26.84 & $88.23 \%$ & 50 & 43.97 & $12.06 \%$ \\
\hline 19 & OC19 & 1134 & 1134.00 & $0 \%$ & 150 & 150.00 & $0 \%$ & 14 & 14.00 & $0 \%$ & 103 & 103.00 & $0 \%$ & 25 & 25.00 & $0 \%$ \\
\hline 20 & OC20 & 609 & 414.53 & $31.93 \%$ & 194 & 132.05 & $31.93 \%$ & 410 & 221.24 & $46.04 \%$ & 48 & 22.06 & $54.04 \%$ & 94 & 63.98 & $31.94 \%$ \\
\hline 21 & OC21 & 705 & 359.05 & $49.07 \%$ & 217 & 137.02 & $36.86 \%$ & 125 & 117.06 & $6.35 \%$ & 45 & 42.14 & $6.36 \%$ & 142 & 95.60 & $32.68 \%$ \\
\hline 22 & OC22 & 908 & 325.64 & $64.14 \%$ & 198 & 123.12 & $37.82 \%$ & 390 & 189.19 & $51.49 \%$ & 72 & 24.89 & $65.43 \%$ & 212 & 84.54 & $60.12 \%$ \\
\hline 23 & OC23 & 179 & 179.00 & $0 \%$ & 134 & 134.00 & $0 \%$ & 141 & 141.00 & $0 \%$ & 28 & 28.00 & $0 \%$ & 112 & 112.00 & $0 \%$ \\
\hline 24 & OC24 & 1045 & 419.89 & $59.82 \%$ & 323 & 178.03 & $44.88 \%$ & 280 & 154.33 & $44.88 \%$ & 98 & 35.22 & $64.06 \%$ & 131 & 72.20 & $44.89 \%$ \\
\hline 25 & OC25 & 1215 & 485.17 & $60.07 \%$ & 465 & 193.40 & $58.41 \%$ & 389 & 161.79 & $58.41 \%$ & 121 & 36.19 & $70.09 \%$ & 144 & 59.89 & $58.41 \%$ \\
\hline 26 & OC26 & 867 & 479.58 & $44.69 \%$ & 313 & 173.14 & $44.68 \%$ & 280 & 154.88 & $44.69 \%$ & 123 & 37.90 & $69.19 \%$ & 120 & 66.38 & $44.68 \%$ \\
\hline 27 & OC27 & 1641 & 613.08 & $62.64 \%$ & 395 & 147.57 & $62.64 \%$ & 285 & 106.48 & $62.64 \%$ & 167 & 56.85 & $65.96 \%$ & 175 & 65.38 & $0 \%$ \\
\hline 28 & OC28 & 1501 & 467.84 & $68.83 \%$ & 533 & 166.13 & $68.83 \%$ & 421 & 131.22 & $68.83 \%$ & 210 & 43.83 & $79.13 \%$ & 234 & 72.93 & $10.30 \%$ \\
\hline
\end{tabular}


Table A5. Comparisons between the actual and projected value with percentage improvement of output variables of opencast mines using VRS DEA.

\begin{tabular}{|c|c|c|c|c|c|c|c|c|c|c|}
\hline NO & DMU & $\begin{array}{l}\text { Actual } \\
\text { OMS }\end{array}$ & $\begin{array}{c}\text { Projected } \\
\text { (OMS) }\end{array}$ & $\%$ Change & Actual CU & $\begin{array}{l}\text { Projected } \\
\text { (CU) }\end{array}$ & $\%$ Change & Actual DP & $\begin{array}{l}\text { Projected } \\
\text { (DP) }\end{array}$ & $\%$ Change \\
\hline 1 & OC1 & 6.1 & 6.10 & $0 \%$ & 106.59 & 106.59 & $0 \%$ & 98.54 & 98.54 & $0 \%$ \\
\hline 2 & OC2 & 1.36 & 5.40 & $297.06 \%$ & 20.87 & 94.03 & $350.55 \%$ & 92 & 92.00 & $0 \%$ \\
\hline 3 & OC3 & 3.95 & 3.95 & $0 \%$ & 102.67 & 102.67 & $0 \%$ & 88.45 & 88.45 & $0 \%$ \\
\hline 4 & OC4 & 2.07 & 2.07 & $0 \%$ & 108.18 & 108.18 & $0 \%$ & 98.69 & 98.69 & $0 \%$ \\
\hline 5 & OC5 & 2.87 & 7.83 & $172.82 \%$ & 26.75 & 87.80 & $228.22 \%$ & 54.07 & 89.98 & $66.41 \%$ \\
\hline 6 & OC6 & 1.63 & 4.30 & $163.80 \%$ & 102.03 & 102.03 & $0 \%$ & 94.41 & 94.41 & $0 \%$ \\
\hline 7 & OC7 & 5.08 & 6.72 & $32.28 \%$ & 23.37 & 100.87 & $331.62 \%$ & 68.12 & 96.25 & $41.29 \%$ \\
\hline 8 & OC8 & 9.14 & 9.14 & $0 \%$ & 50.92 & 50.92 & $0 \%$ & 52.03 & 52.03 & $0 \%$ \\
\hline 9 & OC9 & 2.34 & 2.34 & $0 \%$ & 104.51 & 104.51 & $0 \%$ & 89.24 & 89.24 & $0 \%$ \\
\hline 10 & OC10 & 5.01 & 5.01 & $0 \%$ & 62.37 & 62.37 & $0 \%$ & 81.23 & 81.23 & $0 \%$ \\
\hline 11 & OC11 & 1.08 & 3.48 & $222.22 \%$ & 47.17 & 86.43 & $83.23 \%$ & 58.9 & 80.64 & $36.91 \%$ \\
\hline 12 & OC12 & 2.27 & 2.27 & $0 \%$ & 103.05 & 103.05 & $0 \%$ & 94.28 & 94.28 & $0 \%$ \\
\hline 13 & OC13 & 3.21 & 6.39 & $99.07 \%$ & 57.19 & 94.02 & $64.40 \%$ & 72.54 & 90.03 & $24.11 \%$ \\
\hline 14 & OC14 & 3.11 & 3.11 & $0 \%$ & 95.45 & 95.45 & $0 \%$ & 99.12 & 99.12 & $0 \%$ \\
\hline 15 & OC15 & 3.53 & 8.55 & $142.21 \%$ & 45.95 & 78.64 & $71.14 \%$ & 82.54 & 82.54 & $0 \%$ \\
\hline 16 & OC16 & 3.09 & 7.19 & $132.69 \%$ & 79.39 & 79.39 & $0 \%$ & 72.18 & 80.08 & $10.94 \%$ \\
\hline 17 & OC17 & 1.64 & 6.70 & $308.54 \%$ & 57.8 & 71.20 & $23.18 \%$ & 78.39 & 78.74 & $0.45 \%$ \\
\hline 18 & OC18 & 1.22 & 5.71 & $368.03 \%$ & 101.67 & 101.67 & $0 \%$ & 94.29 & 94.95 & $0.70 \%$ \\
\hline 19 & OC19 & 2.53 & 2.53 & $0 \%$ & 65.44 & 65.44 & $0 \%$ & 69.15 & 69.15 & $0 \%$ \\
\hline 20 & OC20 & 1.97 & 8.82 & $347.72 \%$ & 60.27 & 60.55 & $0.46 \%$ & 52.57 & 61.68 & $17.33 \%$ \\
\hline 21 & OC21 & 7.7 & 7.87 & $2.21 \%$ & 45.45 & 76.44 & $68.18 \%$ & 47.69 & 84.04 & $76.22 \%$ \\
\hline 22 & OC22 & 3.21 & 9.13 & $184.42 \%$ & 64.45 & 64.45 & $0 \%$ & 62.11 & 69.12 & $11.29 \%$ \\
\hline 23 & OC23 & 9.11 & 9.11 & $0 \%$ & 79 & 79.00 & $0 \%$ & 87.5 & 87.50 & $0 \%$ \\
\hline 24 & OC24 & 4.23 & 6.89 & $62.88 \%$ & 78.71 & 84.16 & $6.92 \%$ & 87.65 & 87.65 & $0 \%$ \\
\hline 25 & OC25 & 4.78 & 6.24 & $30.54 \%$ & 82.3 & 86.30 & $4.86 \%$ & 88.1 & 88.10 & $0 \%$ \\
\hline 26 & OC26 & 5.1 & 6.65 & $30.39 \%$ & 72.5 & 80.44 & $10.95 \%$ & 84 & 84.00 & $0 \%$ \\
\hline 27 & OC27 & 3.56 & 6.23 & $75.00 \%$ & 68.9 & 72.24 & $4.85 \%$ & 73.5 & 76.77 & $4.45 \%$ \\
\hline 28 & OC28 & 2.97 & 6.81 & $129.29 \%$ & 61.75 & 80.76 & $30.79 \%$ & 60.25 & 84.28 & $39.88 \%$ \\
\hline
\end{tabular}




\section{References}

1. Energy Statistics. 2020. Available online: http://mospi.nic.in/sites/default/files/publication_reports/ES_2020_ 240420m.pdf (accessed on 11 June 2020).

2. Coal Planning. Available online: www.coalcontroller.gov.in (accessed on 11 June 2020).

3. Brignall, S.; Ballantine, J. Performance measurement in service business revisited. Int. J. Serv. Ind. Manag. 1996, 7, 6-31. [CrossRef]

4. Purbey, S. Development of a Framework for Managing the Performance of Indian Healthcare Units. Ph.D. Thesis, Indian School of Mines, Dhanbad, India, 2008.

5. Thompson, R.G.; Dharmapala, P.; Thrall, R.M. Linked-cone DEA profit ratios and technical efficiency with application to Illinois coal mines. Int. J. Prod. Econ. 1995, 39, 99-115. [CrossRef]

6. Kulshreshtha, M.; Parikh, J.K. Study of efficiency and productivity growth in opencast and underground coal mining in India: A DEA analysis. Energy Econ. 2002, 24, 439-453. [CrossRef]

7. Hosseinzadeh, A.; Smyth, R.; Valadkhani, A.; Le, V. Analyzing the efficiency performance of major Australian mining companies using bootstrap data envelopment analysis. Econ. Model. 2016, 57, 26-35. [CrossRef]

8. Geisslera, B.; Mew, M.C.; Weber, O.; Steiner, G. Efficiency performance of the world's leading corporations in phosphate rock mining. Resour. Conserv. Recycl. 2015, 105, 246-258. [CrossRef]

9. Fang, H.; Wu, J.; Zeng, C. Comparative study on efficiency performance of listed coal mining companies in China and the U.S. Energy Policy 2009, 37, 5140-5148. [CrossRef]

10. Lei, T.; Ding, R.J. Efficiency assessment of coal mine safety input by data envelopment analysis. J. China Univ. Min. Technol. 2008, 18, 88-92.

11. Cui, Y.; Huang, G.; Yin, Z. Estimating regional coal resource efficiency in China using three-stage DEA and bootstrap DEA models. Int. J. Min. Sci. Technol. 2015, 25, 861-864. [CrossRef]

12. Yang, H.; Pollitt, M.G. Incorporating both undesirable outputs and uncontrollable variables into DEA: The performance of Chinese coal-fired power plants. Eur. J. Oper. Res. 2009, 197, 1095-1105. [CrossRef]

13. Wong, W.P.; Wong, K.Y. Supply chain performance measurement system using DEA modeling. Ind. Manag. Data Syst. 2007, 107, 361-381. [CrossRef]

14. Singh, R.; Mahapatra, B.; Mukherjee, K.; Bhar, C. Application of DEA performance Evaluation of Indian Microfinance Institutions. Asian J. Manag. Res. 2014, 4, 597-605.

15. Charnes, A.; Cooper, W.W.; Rhodes, E. Measuring the efficiency of decision-making units. Eur. J. Oper. Res. 1978, 2, 429-444. [CrossRef]

16. Fan, Y.; Bai, B.; Qiao, Q.; Kang, P.; Zhang, Y.; Guo, J. Study on eco-efficiency of industrial parks in China based on data envelopment analysis. J. Environ. Manag. 2017, 192, 107-115. [CrossRef] [PubMed]

17. Malmquist, S. Index numbers and indifference curves. Trab. Estat. 1953, 4, 209-242. [CrossRef]

18. Caves, D.W.; Christensen, L.R.; Diewart, W.E. The econometric theory of index numbers and the measurement of input, and output productivity. Econometrica 1982, 50, 1393-1414. [CrossRef]

19. Fare, R.; Grosskopf, S.; Norris, M.; Zhang, Z. Productivity growth, technical progress, and efficiency change in industrialized countries. Am. Econ. Rev. 1994, 84, 66-83.

20. Kao, C. Network Data Envelopment Analysis-Foundation and Extension; International Series in Operations Research \& Management Science; Springer: Berlin/Heidelberg, Germany, 2017; Volume 240. [CrossRef]

21. Vaninsky, A. Efficiency of electric power generation in the United States: Analysis and forecast based on data envelopment analysis. Energy Econ. 2006, 28, 326-338. [CrossRef]

22. Barros, C.P. Efficiency analysis of hydroelectric generating plants: A case study for Portugal. Energy Econ. 2008, 30, 59-75. [CrossRef]

23. Jamasb, T.; Pollitt, M.; Triebs, T. Productivity and efficiency of U.S. gas transmission companies: A European regulatory perspective. Energy Policy 2008, 36, 3398-3412. [CrossRef]

(C) 2020 by the authors. Licensee MDPI, Basel, Switzerland. This article is an open access article distributed under the terms and conditions of the Creative Commons Attribution (CC BY) license (http://creativecommons.org/licenses/by/4.0/). 